(c) Group of authors, 2018

UDC 616.341-053.2/.4-07

DOI - https://doi.org/10.14300/mnnc.2018.13104

ISSN - 2073-8137

\title{
DIAGNOSIS OF CELIAC DISEASE IN GROUPS OF GENETIC RISK: MODERN VIEW ON THE PROBLEM
}

\author{
Klimov L. Ya. ${ }^{1}$, Stoyan M. V. 1, 2 , Kuryaninova V. A. 1, 2 , Gerasimenko E. S. 1, \\ Kashnikov V. S. 1, 2, Atanesyan R. A. ' , Ivanova A. V. 1', Kochneva L. D. 1 \\ 1 Stavropol State Medical University, Russian Federation \\ 2 G. K. Philippsky Child Clinical Hospital, Stavropol, Russian Federation
}

\section{АИАГНОСТИКА ЦЕАИАКИИ В ГРУППАХ ГЕНЕТИЧЕСКОГО РИСКА: СОВРЕМЕННЫЙ ВЗГАЯА НА ПРОБАЕМУ}

\author{
А. Я. КАимов 1, М. В. Стоян ${ }^{1,2}$, В. А. Курьянинова 1, 2, Е. С. Герасименко 1, \\ В. С. Кашников ${ }^{1,2}$, Р. А. Атанесян ${ }^{1}$, А. В. Иванова ${ }^{1}$, А. А. Кочнева ${ }^{1}$ \\ 1 Ставропольский госуаарственный меАицинский университет, Российская ФеАерация \\ 2 ГороАская Аетская КАиническая больница им. Г. К. ФиАиппского, Ставрополь, \\ Российская ФеАерация
}

Celiac disease is one of the multisystem autoimmune diseases that is being intensively studied due to the very widespread prevalence in almost all regions of the world and extremely adverse effects on the health and quality of life of patients. Timely detection of celiac disease is a problem for many physicians due to the variety of clinical manifestations, the erased, lowsymptom and atypical course of the disease. Screening of celiac disease in groups of genetic risk is recognized as one of the methods of primary prevention of autoimmune and oncological diseases.

Keywords: celiac disease, screening, HLA, type I diabetes, autoimmune thyroid disease, tissue transglutaminase

Целиакия относится к числу мультисистемных аутоиммунных заболеваний, которые интенсивно изучаются в связи с широкой распространённостью практически во всех регионах мира и характеризуются крайне неблагоприятными последствиями для здоровья и качества жизни пациентов. Своевременное выявление целиакии является проблемой для многих врачей из-за разнообразия клинических проявлений, стёртого, малосимптомного и атипичного течения заболевания. Скрининг целиакии в группах генетического риска признан одним из способов первичной профилактики аутоиммунных и онкологических заболеваний.

Ключевые слова: целиакия, скрининг, HLA, сахарный диабет I типа, аутоиммунный тиреоидит, тканевая трансглутаминаза

For citation: Klimov L. Ya., Stoyan M. V., Kuryaninova V. A., Gerasimenko E. S., Kashnikov V. S., Atanesyan R. A., Ivanova A. V., Kochneva L. D. DIAGNOSIS OF CELIAC DISEASE IN GROUPS OF GENETIC RISK: MODERN VIEW ON THE PROBLEM. Medical News of North Caucasus. 2018;13(3):555-560. DOI - https://doi.org/10.14300/mnnc.2018.13104

Для цитирования: Климов Л. Я., Стоян М. В., Курьянинова В. А., Герасименко Е. С., Кашников В. С., Атанесян Р. А., Иванова А. В., Кочнева Л. Д. ДИАГНОСТИКА ЦЕЛИАКИИ В ГРУППАХ ГЕНЕТИЧЕСКОГО РИСКА: СОВРЕМЕННЫЙ ВЗГЛЯД НА ПРОБЛЕМУ. Медицинский вестник Северного Кавказа. 2018;3(3):555-560.

DOI - https://doi.org/10.14300/mnnc.2018.13104

AITD - Autoimmune Thyroid Disease

anti-TTG - antibodies to Tissue Transglutaminase

EMA - anti-Endomysial Antibodies
HLA - Human Leukocyte Antigen

T1DM - Type I Diabetes Mellitus

TTG - Tissue Transglutaminase eliac disease is an immuno-mediated, genetically determined systemic disease that occurs with the use of gluten and/or corresponding prolamines, characterized by the development of atrophic enteropathy, appearance of specific autoantibodies in the blood serum and a wide spectrum of gluten-dependent clinical manifestations [1].
Previously it was believed that celiac disease is a rare disease that occurs in infancy, its frequency in the general population was 1 case per $3000-10,000$ people [2, 3]. However, large-scale epidemiological studies using highly specific serological methods have changed this view and demonstrated a much higher prevalence of the disease in most regions of the world in which cereal crops are traditionally used for feeding children and adults $[4,5,6]$. 
Currently, the prevalence of celiac disease in Europe and the United States is about 1-2\% of the population, or 1:100-1:200 in the general population $[7,8]$. Annually, the number of newly diagnosed cases is increasing all over the world, which is caused by a massive examination of large groups of patients at high risk for celiac disease. The increase in the incidence and prevalence of celiac disease in recent decades is also due to the diagnosis of atypical forms of celiac disease, which are characterized by a smooth clinical picture with a lack or minimal expression of gastrointestinal and predominance of extraintestinal symptoms $[9,10,11]$.

Typical intestinal symptoms dominate only in young children, while in school-aged children and adolescents extraintestinal symptoms often prevail, and many cases of celiac disease continue to be undiagnosed and untreated and cause severe complications in various systems, often associated with the development of other autoimmune diseases [12, 13]. In 1992 R. Logan proposed to consider the prevalence of celiac disease as an «iceberg», in which the surface part consists of cases of a typical form of the disease, and its large underwater part is formed of smooth, asymptomatic and latent forms that create significant difficulties in diagnosis and negatively affect the prognosis for patients [14]. Untreated celiac disease can lead to the development of such serious complications as chronic protein-energy deficiency, autoimmune hepatitis, neuropathy, osteoporosis, malignant intestinal tumors $[15,16]$.

Along with the regional genetic diversity of the human population and the nutritional characteristics observed in different countries, differences in the prevalence of celiac disease are due to the use of diagnostic tests with unequal specificity and sensitivity $[17,18,19]$. A retrospective study of blood samples from adult Americans taken in 1974, 1989 , and 2001 showed that the incidence of serological markers of celiac disease in 1974 was 1:501, in $1989-$ $1: 219$, and in $2001-1: 105$. Obviously, the prevalence of celiac disease in the USA over the past 45 years has increased 5 -fold - from 0.2 to $1 \%$, which certainly requires a comprehensive analysis [20].

Despite the increased attention and quality of diagnosis of celiac disease, the ratio of verified and undiagnosed cases to date is between 1:5 and 1:13 $[14,21]$. In most cases of undiagnosed celiac disease, subclinical asymptomatic flow is observed in patients, and diagnosis is possible through targeted screening, primarily in groups of genetically determined risk [22]

The high-risk group includes first-degree relatives of celiac patients (parents, siblings), patients with other autoimmune diseases, endocrinopathies (diabetes mellitus type I (T1DM), autoimmune thyroid disease (AITD), Addison's disease) and genetic diseases (Down's syndrome, Shereshevsky-Turner syndrome), herpetiform dermatitis of Dühring, etc. [23, 24]

Thanks to the introduction and wide use of modern specific serological diagnostic methods (antibodies to tissue transglutaminase (anti-TTG) IgA, IgG, antiendomysial antibody-EMA) it has became possible to conduct screening and epidemiological studies. The screening of celiac disease among patients in the highrisk group is the primary prevention of autoimmune and oncological diseases [24, 25].

According to the modern model of the pathogenesis of celiac disease, the development of an autoimmune process in the intestinal mucosa is initiated exclusively after the formation of a complex of deamidated gliadin and tissue transglutaminase (TTG) with the «typical» HLADQ2/DQ8 alleles of the main histocompatibility complex of class II [14, 26].
The most important genetic risk factor for the development of celiac disease is the presence of HLADQ2/DQ8 heterodimers. Numerous studies have shown that in 95-98\% of patients with celiac disease there are alleles of the DQ2 molecule (DQA $1{ }^{\star} 0501$, DQB $1{ }^{\star} 0201$ ) and less often - DQ8 (DQA $\left.{ }^{\star} 03, \mathrm{DQB} 1{ }^{\star} 0302\right)$. Class II HLA antigens present gluten oligopeptide to T-cells with their subsequent selective activation and development of pathological immune response. HLA-DQ2 is found in 90$95 \%$ of patients with celiac disease, the rest - HLA-DQ8 [27-30]. The absence of HLA DQ2 / DQ8 alleles makes it possible to consider the development of celiac disease as extremely unlikely [31]. The incidence of HLA-DQ2 and DQ8 in the population is $30-40 \%$, but only a few people with these genotypes develop celiac disease, therefore, the search for other genes involved in the pathogenesis of celiac disease and epigenetic factors not associated with the HLA system continues [32].

HLA testing should not be used routinely, but it is necessary in children and adults in groups of genetic risk (relatives of patients). Identification of their characteristic alleles will be evidence of the need for further close examination [33]. HLA genes are necessary, but not sufficient for the development of celiac disease, not HLA genes are involved. To date, we know 39 genes that do not belong to the HLA system, but are associated with the development of celiac disease. However, individually, each of these non-HLA genes plays a relatively small role in the risk of celiac disease [32].

Despite the various mechanisms of gluten penetration into the sub-epithelial layer of the intestinal wall, the further course of the pathological process is determined by the presence of a genetic predisposition and the intensity of immuno-inflammatory responses of adaptive immunity [14]. The process of presentation of the gluten antigen by the complex of class II HLA looks as follows: the protein antigen, penetrating as a result of increase in the permeability of the intestine into the inner lamina of the mucous membrane, undergoes deamidation of TTG, as a result of which neutral glutamine residues are converted into negatively charged glutamic acid residues. This causes the formation of a gluten-deamidated gliadin peptide, toxic to patients with the left-handed spiral conformation of gluten, which binds to HLA-DQ2 and HLA-DQ8 molecules as much as possible and initiates an immune response $[14,26]$.

The most important factor explaining the multisystem nature of the immunopathological process is the detection of TTG also in the liver, lymph nodes, muscles, blood vessels, therefore, children with celiac disease have $\lg \mathrm{A}$ autoantibodies in these organs and tissues. The mechanism of molecular «mimicry» underlies the formation of cross reactivity and autoaggression to the tissues of the endocrine and nervous systems, leading to the development of autoimmune diseases (type 1 diabetes, AITD, ataxia, individual forms of epilepsy, etc.). Similar variants of the $\mathrm{T}$ - and $\mathrm{B}$-cell responses that arise in genetically determined tissues lead to organ-specific autoimmune diseases due to the wide spread of TTG epitopes in the body [14].

It is generally accepted that in celiac disease the multiple nature of autoimmune lesions of endocrine organs is noted, with both genetic and extrinsic factors involved in pathogenesis. In particular, HLA DR4 and DR3 are associated with type I diabetes, and approximately $30-50 \%$ of patients are DR3/DR4 heterozygotes [34, 35]. DR3/DR4 genotype provides a high risk of diabetes. It was found that HLA-DQ locus (especially DQ2 and DQ8) is the most important determinant of sensitivity to diabetes. Approximately $90 \%$ of people with type 1 
diabetes have DQ2 or DQ8, compared with 30-40\% of the population as a whole. Thus, HLA genotype with a high-risk of type 1 diabetes is DR3-DQ2, DR4-DQ8. The presence of DR3-DQ2 genotype implies a high risk of type 1 diabetes association with celiac disease.

The incidence of celiac disease in patients with type I diabetes is 4.4-11.1\% [34]. The mechanism of association of these two diseases includes a common genetic background: HLA DR3-DQ2 genotype and DR4DQ8 are closely related to diabetes, HLA DR3-DQ2 - to celiac disease. Classical development of celiac disease in patients with type 1 diabetes is extremely rare, most patients have extraintestinal manifestations or completely no symptoms of the disease. In fact, celiac disease is diagnosed by screening among patients with type 1 diabetes. The age of onset of type 1 diabetes in patients with a double autoimmune disease is usually younger than in patients with diabetes alone [36]. A higher risk of developing celiac disease is observed in children younger than 4 years old than those over the age of 9 [37]. In most cases, type 1 diabetes is first diagnosed, and only in 10$25 \%$ of cases celiac disease precedes diabetes [34, 38]. As a rule, diagnosis of celiac disease in patients with type 1 diabetes occurs through screening after diabetes.

Fasano A. et al. believe that there are other common links in the pathogenesis of celiac disease and type I diabetes in addition to the general genotype. It was found that the zonulin protein similarly affects patients with celiac disease and type I diabetes, with zonulin becoming active during the acute phase of celiac disease, leading to an increase in the permeability of the intestinal lumen [39]. Another study showed that gliadin releases zonulin and causes an increase in intestinal permeability, and against a background of a gluten-free diet, zonulin levels and intestinal permeability decreased [40].

The presence of autoantibodies to tissue transglutaminase is associated with DQ2 and DQ8, and in particular, with the DQ2 homozygosity. One study showed that $98(11.6 \%)$ of 847 patients with type 1 diabetes had antibodies to TTG. Homozygosity for DR3-DQ2 in the population of patients with type 1 diabetes carries a $33 \%$ risk of having anti-TTG [41].

Some authors suggest that in genetically susceptible patients one disease may predispose to the development of another. In particular, latent celiac disease may be an immunological trigger and can induce diabetes and/or thyroid disease, and the main antigen here will be gluten [42]. The development of autoimmune diseases in celiac disease is associated with the age of diagnosis and the duration of gluten exposure [43]. In other studies, no correlation was found between the duration of exposure to gluten and the risk of developing autoimmune disorders [44].

Gastrointestinal disorders with typical enteral syndrome in patients with type 1 diabetes are extremely rare-up to $10 \%$; in most patients with diabetes, celiac disease is asymptomatic, or its course is associated with extraintestinal symptoms [34, 42]. In addition, patients may have positive autoantibodies without atrophy of the jejunum mucosa. This condition is called «potential celiac disease." A multicentre study in Italy, involving 8717 patients with type 1 diabetes, showed that the prevalence of potential celiac disease in this group of patients is $12.2 \%$ [45].

In a study by Tosco A. et al. it is shown that in $30 \%$ of patients with potential celiac disease, apparent clinical symptomatology develops within 3 years of observation, emphasizing the need for repeated serological testing [46]. This study included 106 children with positive autoantibodies and normal jejunum mucosa. Celiac disease was detected in $40.6 \%$ of patients at risk (type 1 diabetes, AITD, first-degree relatives with celiac disease), 97 of 99 patients had HLA-DQ2 and/or HLA-DQ8 alleles.

Patients with type I diabetes should be screened in the following periods: during the diabetes manifestation period, annually during the first 4 years of follow-up, and every 2 years for the next 6 years $[47,48]$. It is recomended to use anti-TTG IgA (confirmed by EMA) and IgG (if there is a selective IgA deficiency) as serological screening methods. If the screening result is positive, confirmation of the diagnosis of celiac disease should be performed in accordance with the criteria of ESPGHAN-2012 [49].

Autoimmune thyroid diseases also have common pathogenetic links to celiac disease. The incidence of AITD in patients with celiac disease varies from 4.1 to $14.0 \%[42,50]$. In earlier publications, the relationship of celiac disease and hyperthyroidism has been described, but in later studies a large association with hypothyroidism is indicated [42]. The effect of compliance with a glutenfree diet for 1 year resulted in normalization of subclinical hypothyroidism. This association is genetically determined due to the much more frequent detection of common B8 and DR3 HLA-haplotypes in patients with celiac disease and autoimmune thyroid diseases [42]. It should be noted that the HLA DR antigen was also detected in children and adults with Sj gren's syndrome.

The study, in which antibodies to gliadin and TTG were used as a serological screening, enrolled 115 patients with Graves' disease, among which the prevalence of celiac disease was $4.5 \%$, while clinically celiac disease was asymptomatic [51]. Cases of malignant thyroid lymphomas are described that complicate the course of celiac disease [42]. It is assumed that the development of an autoimmune process may take some time, therefore, all patients with hypothyroidism and hyperthyroidism with a certain periodicity should be serologically screened for celiac disease.

The prevalence of celiac disease among relatives of patients is significantly higher than in the general population - from 5 to $20 \%[33,52]$. The highest frequency of celiac disease detection is noted among first-degree relatives. In a multicentre study conducted in the United States among 13,145 showed that the frequency of celiac disease among the fierst-degree relatives was 1:22, second-degree - 1:39, and in the control group - 1:133 [53]. Another study, involving 107 families with two or more children with celiac disease, showed a 3-fold increase in the risk of celiac disease, as well as the prevalence of new cases of celiac disease in males [54]. The most important predictor of family risk is the transference of HLA-DQ2, where brothers and sisters have the maximum risk [55]

In a study by Rubio-Tapia $A$. et al. which enrolled 344 first-degree relatives positive anti-TTG IgA was detected in $47(14.0 \%)$ patients ( 8 parents, 13 children, 26 siblings), 33 of them had positive EMA. After morphological and genetic examination, celiac disease was diagnosed in 39 patients. Only $13 \%$ of patients had a typical form of celiac disease, $33 \%$ had an atypical clinic in the form of constipation, increased fatigue with musculoskeletal pain and iron deficiency anemia, and in $54 \%$ of cases celiac disease was asymptomatic despite of severe atrophy of the jejunum mucosa. In all newly detected cases HLA DQ2/DQ8 haplotypes were found [56].

In Castro-Antunes M. M. et al. study (Brazil), serological screening for celiac disease was conducted in 174 first-degree relatives of patients with celiac disease. Positive antibodies to tissue IgG transglutaminase were detected in 34 (20.1\%) cases (95\% Cl: 14.6-26.5). After histological confirmation (grade 3 Marsh atrophy), the 
estimated prevalence of celiac disease was $11.5 \%$ (95\% Cl: 7.3-17.4) [57].

It is indisputable that all the relatives of patients with celiac disease should be screened, but there is no specific data, when and how often to examine them. Goldberg D. et al. in their study showed the need for repeated testing for celiac disease, regardless of the presence of symptoms [58]. Re-examination of 171 family members with initially negative endomysial antibodies, tested several times, revealed $6(3.5 \%)$ positive results. Mean seroconversion time was $1.7 \pm 1.2$ years (from 6 months to 3 years 2 months). And none of the patients had any change in symptoms between testing.

A survey of 1612 adult celiac patients in the USA showed that the symptoms had been present on average 11 years before the diagnosis [59]. Timely diagnosis of celiac disease was observed in $52 \%$ of cases. The study demonstrated a late diagnosis of the disease, leading to an increased risk of small intestine neoplasms.

According to numerous publications, at the first stage it is necessary to determine the level of anti-TTG IgA, IgG. TTG IgA test is the standard method for children older than 2 years. If the serological result is positive, it is necessary to confirm celiac disease by jejunal biopsy and HLA typing. Intestinal biopsy can also be performed if the clinical suspicion of celiac disease is high, but serological tests are negative. It is suggested that a combination of positive serological tests can be used to diagnose celiac disease as an alternative to biopsy. HLA-DQ2/DQ8 typing serves as an additional test in the genetic counseling of families with celiac disease to determine patients at high risk of the disease. The absence of HLA DQ2/DQ8 alleles is very likely to indicate a very low risk of celiac disease [60].

Thus, to date, there is no doubt that celiac disease is a very common disease that occurs at any age and in all regions of the world. Over the past two to three decades, there has been a distinct tendency to increase шт the incidence of celiac disease worldwide. Prevention of autoimmune diseases should be aimed at the widespread introduction of modern serological methods of laboratory diagnosis for screening and active detection of celiac disease in groups of high genetic risk. Timely detection of celiac disease and the appointment of a gluten-free diet will prevent the progression of both the disease itself and its complications.

\section{Disclosures:}

The authors declare no conflict of interest.

Acknowledgements. The work was supported by the state task of the Ministry of Health of the Russian Federation «Identification of celiac disease among relatives of 1 degree of kinship of patients with celiac disease».

\section{References}

1. Parfenov A. I., Bykova S. V., Sabelnikova E. A., Maev I. V., Baranov A. A. [et al.] All-Russian Consensus on Diagnosis and Treatment of Celiac Disease in Children and Aduits. Ter. Arkh. 2017;89(3):94-107.

https://doi.org/10.17116/terarkh201789394-107

2. Barada K., Abu Daya H., Rostami K., Catassi C. Celiac disease in the developing world. Gastrointest. Endosc. Clin. N. Am. 2012;22(4):773-793.

https://doi.org/10.1016/j.giec.2012.07.002

3. Belmer S. V. Epidemiology of celiac disease: facts and conclusions. Lechaschi Vrach. 2013;1:16-19.

4. Mustalahti K., Catacci C., Reunanen A., Fabiani E., Heier M. [et al.] The prevalence of celiac disease in Europe: results of a centralized, international mass screening project. Ann. Med. 2010;42(8):587-595. https://doi.org/10.3109/07853890.2010.505931

5. Ludvigsson J. F., Rubio-Tapia A., van Dyke C. T., Melton L. J. 3rd, Zinsmeister A. R. [et al.] Increasing incidence of celiac disease in a North American population. Am. J. Gastroenterol. 2013;108(5):818-824. https://doi.org/10.1038/ajg.2013.60

6. Catassi C., Gatti S., Lionetti E. World perspective and celiac disease epidemiology. Dig. Dis. 2015;33(2):141-146. https://doi.org/10.1159/000369518

7. Catassi C., Gatti S., Fasano A. The new epidemiology of celiac disease. J. Pediatr. Gastroenterol. Nutr. 2014;59 (Suppl.1):S7-9.

https://doi.org/10.1097/01.mpg.0000450393.23156.59

8. Rubio-Tapia A., Ludvigsson J. F., Brantner T. L., Murray J. A., Everhart J. E. The prevalence of celiac disease in the United States. Am. J. Gastroenterol. 2012;107(10): 1538-1544. https://doi:10.1038/ajg.2012.219

9. Reilly N. R., Green P. H. Epidemiology and clinical presentations of celiac disease. Semin. Immunopathol. 2012; 34(4):473-478.

https://doi.org/10.1007/s00281-012-0311-2

10. Klimov L., Stoyan M., Kuryaninova V., Eremeeva O., Kashnikov V. [et al.] Improving of the diagnosis of celiac disease in children in Stavropol territory: retrospective analysis of 17 years. Medical News of North Caucasus. $2014 ; 9(3): 237-241$

https://doi.org/10.14300/mnnc.2014.09067
11. Yankina G. N., Loshkova E. V., Kondratyeva E. I., Zhelev V. A., Mikhalev E. V. Comorbidity in celiac disease. J. Pediatria. 2017;96(6):140-149. https://doi.org/10.24110/0031-403X-2017-96-6-140-149

12. Dmitrieva Yu. A., Zakharova I. N. Neurologic manifestations in coeliac disease patients. Meditsinsky sovet (Medical Council). 2017;9:93-96. https://doi.org/10.21518/2079-701X-2017-9-93-96

13. Zakharova I. N., Dmitrieva Yu. A., Dzebisova F. S. Celiac disease and associated diseases. Russian Bulletin of perinatology and pediatrics. 2014;59(3):44-49.

14. Celiac disease in children. Edited by S. V. Belmer, M. O. Revnova. M.: MedPraktika-M, 2015.

15. Green P. H., Fleischauer A. T., Bhagat G., Goyal R., Jabri B. [et al.] Risk of malignancy in patients with celiac disease. Am. J. Med. 2003;115(3):191-195.

16. Rubio-Tapia A., Kyle R. A., Kaplan E. L., Johnson D. R., Page W. [et al.] Increased prevalence and mortality in undiagnosed celiac disease. Gastroenterology. 2009;137(1): 88-93. https://doi.org/10.1053/i.gastro.2009.03.059

17. Matysiak-Budnik T., Moura I. C., Arcos-Fajardo M., Lebreton C., Ménard S. [et al.] Secretory IgA mediates retrotranscytosis of intact gliadin peptides via the transferrin receptor in celiac disease. J. Exp. Med. 2008;205(1): 143-154. https://doi.org/10.1084/jem.20071204

18. Lagerqvist C., Dahlbom I., Hansson T., Jidell E., Juto P. [et al.]. Antigliadin immunoglobulin A best in finding celiac disease in children younger than 18 months of age. J. Pediatr. Gastroenterol. Nutr. 2008;47(4):428-435. https://doi.org/10.1097/MPG.0b013e31817d80f4

19. Arigliani M., Rech Morassutti F., Fabris M., Melli P., Tonutti E. [et al.] Coeliac disease in infants: antibodies to deamidated gliadin peptide come first! Ital. J. Pediatr. 2017;43(1):70. https://doi.org/10.1186/s13052-017-0392-6

20. Catassi C., Kryszak D., Bhatti B., Sturgeon C., Helzlsouer K. [et al.] Natural history of celiac disease autoimmunity in a USA cohort followed since 1974. Ann. Med. 2010;42(7):530-538

https://doi.org/10.3109/07853890.2010.514285

21. Gibson P. R., Shepherd S. J., Tye-Din J. A. For celiac disease, diagnosis is not enough. Clin. Gastroenterol. Hepatol. 2012;10(8):900-901. https://doi.org/10.1016/j.cgh.2012.03.020 
22. Barker J. M., Liu E. Celiac disease: pathophysiology, clinical manifestations, and associated autoimmune conditions. Adv. Pediatr. 2008;55:349-365.

23. Denham J. M., Hill I. D. Celiac disease and autoimmunity: review and controversies. Curr. Allergy Asthma Rep. 2013;13(4):347-353. https://doi.org/10.1007/s11882-013-0352-1

24. Savvateeva L. V., Erdes S. I., Antishin A. S., Zamyat$\operatorname{nin}$ A. A. Jr. Current paediatric coeliac disease screening strategies and relevance of questionnaire survey. Int. Arch Allergy Immunol. 2018;27:1-11. https://doi.org/10.1159/000491496

25. Zakharova I. N., Dmitrieva Yu. A., Klimov L. Y., Dzebisova F. S. Controversial issues of prophylaxis of celiac disease. Meditsinsky sovet (Medical Council). 2015;14:119-122.

26. Shumilov P. V., Muhina Y. G., Netrebenko O. K., Ryazanova O. V., Schigaleva N. E. [et al.] Modern understanding of celiac disease pathogenetic mechanisms: defining role in course clinical variants. J. Pediatria. 2016;95(6):110-121.

27. Dieli-Crimi R., Cénit M. C., Núñez C. The genetics of celiac disease: A comprehensive review of clinical implications. J. Autoimmun. 2015;64:26-41.

https://doi.org/10.1016/j.jaut.2015.07.003

28. Kasatkina E. N., Dmitrieva Yu. A., Roslavtseva E. A., Borovic T. E., Zakharova I.N. Distribution of HLA-DR-DQ genotypes in Russian children with coeliac disease. J. Pediatr. Gastroenterol. Nutr. 2018:66 (suppl. 1):S151-151.

29. Klimov L. Ya., Kuryaninova V. A., Stoyan M. V., Zakharova I. N., Dmitrieva Yu. A. [et al.] HLA-DQ in patients with coeliac disease living in South Russia. J. Pediatr. Gastroenterol. Nutr. 2018;64 (suppl.1):S197-197.

30. Kondrateva E. I., Yankina G. N., Dolbneva O. V. Incidence of polymorphic variants of HLA DQA1 and DQB1 genes in patients with celiac disease in the cities Tomsk and Krasnodar. Pediatric Nutrition. 2012;10(2):11-14

31. Wolters V. M., Wijmenga C. Genetic background of celiac disease and its clinical implications. Am. J. Gastroenterol. 2008;103(1):190-195

https://doi.org/10.1111/j.1572-0241.2007.01471.x

32. Kumar V., Wijmenga C., Withoff S. From genome-wide association studies to disease mechanisms: celiac disease as a model for autoimmune diseases. Semin. Immunopathol. 2012;34(4):567-580

https://doi.org/10.1007/s00281-012-0312-1

33. Freeman $\mathrm{H}$. J. Risk factors in familial forms of celiac disease. World J. Gastroenterol. 2010;16(15):1828-1831.

34. Camarca M. E., Mozzillo E., Nugnes R., Zito E., Falco M. [et al.] Celiac disease in type 1 diabetes mellitus. Ital. J. Pediatr. 2012;38:10.

https://doi.org/10.1186/1824-7288-38-10

35. Smigoc Schweiger D., Mendez A., Kunilo Jamnik S., Bratanic N., Bratina N. [et al.] High-risk genotypes HLA-DR3-DQ2/DR3-DQ2 and DR3-DQ2/DR4-DQ8 in co-occurrence of type 1 diabetes and celiac disease. Autoimmunity. 2016;49(4):240-247.

https://doi.org/10.3109/08916934.2016.1164144

36. Kaspers S., Kordonouri O., Schober E., Grabert M., Hauffa B. P. [et al.] Anthropometry, metabolic control, and thyroid autoimmunity in type 1 diabetes with celiac disease: A multicenter survey. J. Pediatr. 2004;145(6):790-795.

37. Cerutti F., Bruno G., Chiarelli F., Lorini R., Meschi F. [et al.] Younger age at onset and sex predict celiac disease in children and adolescents with type 1 diabetes: an Italian multicenter study. Diabetes Care. 2004;27(6):1294-1298.

38. Valerio G., Maiuri L., Troncone R., Buono P., Lombardi F. [et al.] Severe clinical onset of diabetes and increased prevalence of other autoimmune diseases in children with coeliac disease diagnosed before diabetes mellitus. Diabetologia. 2002;45(12):1719-1722.

39. Fasano A., Not T., Wang W., Uzzau S., Berti I. [et al.] Zonulin, a newly discovered modulator of intestinal permeability, and its expression in coeliac disease. Lancet. 2000;355(9214):1518-1519.

40. Visser J., Rozing J., Sapone A., Lammers K., Fasano A. Tight junctions, intestinal permeability, and autoimmunity: celiac disease and type 1 diabetes paradigms. Ann. N. Y. Acad. Sci. 2009;1165:195-205. https://doi.org/10.1111/j.1749-6632.2009.04037.x

41. Bao F., Yu L., Babu S., Wang T., Hoffenberg E. J. [et al.] One third of HLA DQ2 homozygous patients with type 1 diabetes express celiac disease-associated transglutaminase autoantibodies. J. Autoimmun. 1999;13(1):143-148.
42. Freeman H. J. Endocrine manifestations in celiac disease. World J. Gastroenterol. 2016;22(38):8472-8479.

43. Diamanti A., Capriati T., Bizzarri C., Ferretti F., Ancinelli M. [et al.] Autoimmune diseases and celiac disease which came first: genotype or gluten? Expert Rev. Clin. Immunol. 2016;12(1):67-77. https://doi.org/10.1586/1744666X.2016.1095091

44. Viljamaa M., Kaukinen K., Huhtala H., Kyrönpalo S., Rasmussen M. [et al.] Coeliac disease, autoimmune diseases and gluten exposure. Scand. J. Gastroenterol. 2005;40(4):437-443

45. Franzese A., lafusco D., Spadaro R., Cavaliere O., Prisco F. [et al.] Potential celiac disease in type 1 diabetes: a multicenter study. Diabetes Res. Clin. Pract. 2011;92(1):53-56. https://doi.org/10.1016/j.diabres.2010

46. Tosco A., Salvati V.M., Auricchio R., Maglio M., Borrelli M. [et al.] Natural history of potential celiac disease in children. Clin. Gastroenterol. Hepatol. 2011;9(4):320325. https://doi.org/10.1016/j.cgh.2010.09.006

47. Peretti N., Bienvenu F, Bouvet C Fabien N., Tixier F. [et al.] The temporal relationship between the onset of type 1 diabetes and celiac disease: a study based on immunoglobulin an antitransglutaminase screening. Pediatrics. 2004;113(5):e418-422.

48. Karavanaki K., Kakleas K., Paschali E., Kefalas N., Konstantopoulos I. [et al.] Screening for associated autoimmunity in children and adolescents with type 1 diabetes mellitus (T1DM). Horm. Res. 2009;71(4):201206. https://doi:10.1159/000201108

49. Husby S., Koletzko S., Korponay-Szabó I. R., Mearin M. L., Phillips A. [et al.] European Society for Pediatric Gastroenterology, Hepatology, and Nutrition guidelines for the diagnosis of coeliac disease. J. Pediatr. Gastroenterol. Nutr. 2012;54(1):136-160. https://doi.org/10.1097/MPG.0b013e31821a23d0

50. Lodhi M. U., Stammann T., Kuzel A. R., Syed I. A., Ishtiaq R. [et al.] Celiac disease and concomitant conditions: A case-based review. Cureus. 2018;10(2):e2143. https://doi.org/10.7759/cureus.2143

51. Ch'ng C. L., Biswas M., Benton A., Jones M. K., Kingham J. G. Prospective screening for coeliac disease in patients with Graves' hyperthyroidism using anti-gliadin and tissue transglutaminase antibodies. Clin. Endocrinol. (Oxf). 2005;62(3):303-306.

52. Doğan Y., Yildirmaz S., Ozercan I. H. Prevalence of celiac disease among first-degree relatives of patients with celiac disease. J. Pediatr. Gastroenterol. Nutr. 2012;55(2):205208. https://doi.org/10.1097/MPG.0b013e318249378c

53. Fasano A., Berti I. Gerarduzzi T., Not T, Colletti R. B. [et al.] Prevalence of celiac disease in at-risk and not-atrisk groups in the United States: a large multicenter study. Arch. Intern. Med. 2003;163(3):286-292.

54. Gudjónsdóttir A. H., Nilsson S., Ek J., Kristiansson B. Ascher $\mathrm{H}$. The risk of celiac disease in 107 families with at least two affected siblings. J. Pediatr. Gastroenterol. Nutr. 2004;38(3):338-342.

55. Singh P., Arora S., Lal S., Strand T. A., Makharia G. K. Risk of Celiac Disease in the First- and Second-Degree Relatives of Patients With Celiac Disease: A Systematic Review and Meta-Analysis. Am. J. Gastroenterol. 2015;110(11):1539-1548. https://doi.org/10.1038/ajg.2015.296

56. Rubio-Tapia A., van Dyke C. T., Lahr B. D., Zinsmeister A. R., El-Youssef M. [et al.] Predictors of family risk for celiac disease: a population-based study. Clin. Gastroenterol. Hepatol. 2008;6(9):983-987. https://doi.org/10.1016/j.cgh.2008.04.008

57. Castro-Antunes M. M., Magalhães R., Nobre L. M., Duarte B. P., Silva G. A. Celiac disease in first-degree relatives of patients. J. Pediatr (Rio J). 2010;86(4):331-336. https://doi:10.2223/JPED.2013

58. Goldberg D., Kryszak D., Fasano A., Green P. H. Screening for celiac disease in family members: is follow-up testing necessary? Dig. Dis. Sci. 2007;52(4):1082-1086.

59. Green P. H. R., Stavropoulos S. N., Panagi S. G., Goldstein S. L., Mcmahon D. J. [et al.] Characteristics of adult celiac disease in the USA: results of a national survey. $\mathrm{Am}$. J. Gastroenterol. 2001:96(1):126-131.

60. Rubio-Tapia A., Hill I. D., Kelly C. P., Calderwood A. H., Murray J. A. ACG clinical guidelines: diagnosis and management of celiac disease. Am. J. Gastroenterol. 2013;108(5):656-676

https://doi.org/10.1038/ajg.2013.79 


\title{
About authors:
}

Klimov Leonid Yakovlevich, PhD in medicine, Associate Professor, Head of the Depatment of Faculty Pediatrics; tel.: +79289630261; e-mail: klimov_leo@mail.ru

Stoyan Marina Valeryevna, PhD in medicine, Assistant Lecture of the Department of Faculty Pediatrics, gastroenterologist of Philippsky Child Clinical Hospital; tel.: +79282447990; e-mail: marina-stoyan@mail.ru

Kuryaninova Victioria Aleksandrovna, PhD in medicine; tel.: +79282938069; e-mail: vichkak@mail.ru

Gerasimenko Elena Sergeevna, Postgraduate student of the Department of Faculty Pediatrics;

tel.: +79886785715; e-mail: drelena555@yandex.ru

Kashnicov Vyacheslav Stanislavovich, MD, Associate Professor of the Department of Polyclinic Pediatrics, Head doctor; tel.: +79054961335; e-mail: 721771@mail.ru

Atanesyan Roza Arturovna, PhD in medicine, Assistant Lecture of the Department of Faculty Pediatrics; tel.: +79283770998; e-mail: rozaatanesyan@rambler.ru

Ivanova Alla Viktorovna, Postgraduate student; tel.: +79298380408; e-mail: ivanova1907@list.ru

Kochneva Lyubov Dmitrievna, student; tel.: +79054420367; e-mail: kochneva.Iyubov.96@mail.ru

(C) Group of authors, 2018

UDC 615.828:614.23

DOI - https://doi.org/10.14300/mnnc.2018.13105

ISSN - 2073-8137

\section{OSTEOPATHY IS A NEW MEDICAL SPECIALTY. ASSESSMENT OF CLINICAL EFFECTIVENESS OF OSTEOPATHIC MANIPULATIVE THERAPY IN VARIOUS DISEASES}

\author{
Potekhina Yu. P. 1, Tregubova E. S. ${ }^{2,3}$, Mokhov D. E. ${ }^{2,3}$ \\ 1 Institute of Osteopathy, St. Petersburg, Russian Federation \\ 2 North-Western I. I. Mechnikov State Medical University, St. Petersburg, Russian Federation \\ ${ }^{3}$ St. Petersburg State University, Russian Federation

\section{ОСТЕОПАТИЯ - НОВАЯ МЕАИЦИНСКАЯ СПЕЦИААЬНОСТЬ. ОЦЕНКА КАИНИЧЕСКОЙ ЭФФЕКТИВНОСТИ ОСТЕОПАТИЧЕСКОГО АЕЧЕНИЯ ПРИ РАЗАИЧНЫХ ЗАБОАЕВАНИЯХ}

\author{
Ю. П. Потехина ${ }^{1}$, Е. С. Трегубова ${ }^{2,3}$, А. Е. Мохов ${ }^{2,3}$ \\ ${ }^{1}$ Институт остеопатии, Санкт-Петербург, Российская ФеАерация \\ 2 Северо-ЗапаАный госуАарственный меАицинский университет им. И. И. Мечникова, \\ Санкт-Петербург, Российская ФеАерация \\ 3 Санкт-Петербургский госуаарственный университет, Российская ФеАерация
}

The review shows the effectiveness of osteopathic manipulative therapy (OMT) of various diseases basing on randomized controlled trials. OMT reduces pain and increases the mobility of joints and spine in musculoskeletal diseases. OMT has an analgesic effect. It influences on the peripheral and central links of the nociceptive system, and activates the antinociceptive system. OMT gives good results in functional disorders such as urinary incontinence in women, irritable bowel syndrome, and postoperative ileus. OMT improves the lymph flow and the lymphatic drainage, which is extremely difficult to obtain by other methods. Osteopathic treatment is safe. It provides an individual approach to patients, allows reducing the drug load. It can be successfully combined with other treatment methods. OMT complements the toolkit of clinical medicine and can take its rightful place in the system of provision of medical care to the population.

Keywords: osteopathy, osteopathic manipulative therapy, functional disorders, musculoskeletal disorders, pain

Показана эффективность остеопатического лечения различных заболеваний на основе контролируемых рандомизированных исследований. Остеопатическое лечение уменьшает боль, увеличивает подвижность суставов и позвоночника при костно-мышечных заболеваниях, оказывает противоболевое действие, влияя на периферические и центральные звенья ноцицептивной системы и активируя антиноцицептивную систему. Остеопатическое лечение дает хорошие результаты при функциональных расстройствах, таких как недержание мочи у женщин, синдром раздраженного кишечника, послеоперационная кишечная непроходимость. Остеопатическое лечение улучшает лимфодренаж тканей и лимфоток, что крайне затруднительно получить другими методами воздействия на организм. Остеопатическое лечение безопасно, обеспечивает индивидуальный подход к пациентам, позволяет снизить лекарственную нагрузку, хорошо сочетается с другими методами лечения. Остеопатическое лечение дополняет арсенал клинической медицины и может занять достойное место в системе оказания медицинской помощи населению.

Ключевые слова: остеопатия, остеопатическое лечение, функциональные расстройства, костно-мышечные заболевания, боль 